Funding: See page 225

Peer review: This article has been subject to a double blind peer review process

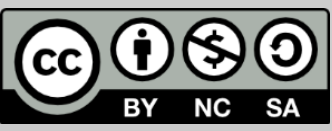

(C) Copyright: The Authors. This article is issued under the terms of the Creative Commons Attribution NonCommercial Share Alike License, which permits use and redistribution of the work provided that the original author and source are credited, the work is not used for commercial purposes and that any derivative works are made available under the same license terms.

\section{'Forging change'? Collaboration between policy makers, academics, and civil society stakeholders at the ECI Day 2016}

\author{
Lucy Hatton*
}

Department of Politics and International Studies, University of Warwick

*Correspondence: L.M.Hatton@Warwick.ac.uk

\begin{abstract}
The 'ECl Day 2016: Forging Change' conference brought together policy makers, academics and civil society representatives to discuss how to maximise the effectiveness of the European Citizens' Initiative (ECI), the EU's only mechanism of participatory democracy, within its existing rules. Since 2012 these annual conferences have brought together a significant number of interested parties to evaluate the performance of the $\mathrm{ECl}$ and look to its future. Through a series of workshops and plenary sessions during ECI Day 2016, participants from diverse backgrounds interacted to produce a number of conclusions that will hopefully be used to inform the future development of the $E C l$ tool. This review focuses on how the representatives of the EU's institutions, academics and civil society representatives collaborated to create a productive environment and reach a clear conclusion to the proceedings. This was a strength of the conference that will hopefully contribute to 'forging change' for the $\mathrm{ECl}$, though resistance to reform from one key stakeholder remains an obstacle.
\end{abstract}

Keywords: collaboration; political participation; European Union; civil society; academia; political institutions

\section{Background and aims}

The European Citizens' Initiative (ECI) is an instrument of participatory democracy introduced in the Lisbon Treaty, the EU's most recent Treaty, which came into force in 2009 (European Union 2007). The ECl connects EU citizens with EU law-making institutions by enabling one million citizens to come together and invite the European Commission to propose a legal act, within their competences. A committee of seven EU citizens from seven different member states can put a proposal to the European Commission, which then decides whether or not the issue is within its powers to propose a legal act. If the Commission decides to 
register the proposal as an $\mathrm{ECl}$ at this stage, the committee has one year in which to collect the one million required signatures from across at least seven EU member states, in order to trigger a public debate in the European Parliament and an official response from the European Commission. It was first launched for use on 1 May 2012 and as of April 2017 there have been $63 \mathrm{ECls}$ proposed to the European Commission, with 43 of these being approved for registration and signature collection. 14 of these 43 were withdrawn before the end of their one year of signature collection, six are currently in the signature collection phase and just three of the remaining 23 successfully collected one million signatures from at least seven member states within one year. However, the European Commission has not yet made any legislative proposals as a direct consequence of these campaigns.

Every April since 2012 the European Economic and Social Committee (EESC), an institution of the EU with the purpose of facilitating civil society engagement with EU policy making, has hosted an 'ECI day' event to reflect on the progress and performance of the instrument over the previous year and look ahead to the future. The rules by which the ECI works are set out in EU Regulation 211/2011 (European Union 2011). The $\mathrm{ECl}$ Regulation was reviewed in 2015 after having been operational for three years and the EU institutions had the opportunity to revise it at that time, but they did not do so. The European Commission in particular was reluctant to adjust the $\mathrm{ECl}$ rules so early on in its life. Consequently, the aims of the ECI Day 2016, which had the title, quite simply, 'Forging Change', were to discuss how to make the $\mathrm{ECl}$ as effective as possible within the current rules. The conference held on 20 April 2016 brought together over 150 participants, including representatives of the EU institutions, academics, civil society stakeholders and the general public, to discuss how to maximise the impact of the $\mathrm{ECl}$ instrument and how participatory democracy in the EU could be enhanced. In this article I explore how participants with diverse academic, policy making and civil society backgrounds interacted during the ECI Day 2016, with a particular focus on one of three core workshops that took place during the event, and how these interactions informed the conclusions of the conference.

\section{What happened at the event}

The conference was organised around two plenary debates and three smaller workshop sessions, throughout which the participants, policy makers, academics and civil society representatives addressed the key themes of the day. The morning began with a plenary session with representatives of some of the EU's institutions central to the $\mathrm{ECl}$ process, including the European Ombudsman Emily O'Reilly, Member of 
the European Parliament and author of its 2015 ECl Report György Schöpflin, Eric Stokkink, Head of the Department for Democracy Affairs in the Netherlands, speaking in the context of the Dutch Presidency of the Council of the European Union, and Elisabeth Goldberg from the Secretariat General of the European Commission. Frustration was voiced from the panel, the audience and on social media that the European Commissioner responsible for the $\mathrm{ECl}$, Frans Timmermans, had cancelled his registration for the event and instead sent Goldberg to speak on the Commission's behalf, without providing a clear explanation. Writing after the conference, civil society organisation The ECl Campaign (an organisation set up to assist users of the $\mathrm{ECl}$ and to campaign for its effective usage) commented that:

'Unfortunately, no Commission representative capable of discussing this decision [not to reform the $\mathrm{ECl}$ Regulation in 2015] was even present at the event. Commissioner Frans Timmermans cancelled his own participation and sent an administrative staffer who could not address political decisions' (The ECI Campaign 2016).

There was therefore a general feeling at the conference, expressed during the plenary session, that any outcomes and proposals generated throughout the day would ultimately have limited effectiveness given one of the key stakeholders was not present to participate.

Following the plenary session, three workshops on important questions regarding the $\mathrm{ECl}$ and participatory democracy ran simultaneously. One explored how an $\mathrm{ECl}$ campaign that has not led to the European Commission making a legislative proposal can maximise its impact in other ways. Dr James Organ from the University of Liverpool School of Law and Social Justice, and Janice Thomson of the The ECI Campaign chaired this workshop, and the panel consisted of organisers of two ECls, one that had successfully collected one million signatures but had not triggered a legislative proposal, and one that had not managed to collect one million signatures in the designated one year timeframe. This was the least attended of the three workshops. Its output consisted of an 'impact tree' identifying the different ways ECls can have impact beyond the possibility of the European Commission generating a relevant legislative proposal, for example by initiating dialogue between policy makers and campaigners and raising public awareness of campaign issues.

Workshop two also included speakers from a range of backgrounds. This workshop focused on the question of 'what future for participatory democracy in the EU?' and considered the lessons the ECl could have for the future of popular participation in the EU. Elisa Lironi, a representative of the non-governmental organisation European Citizens' Action Service 
(ECAS), which campaigns for citizen empowerment in the EU, chaired this workshop. Speaking on the panel were myself, with an academic background in democracy, political participation and the $\mathrm{ECl}$, Roman Haken from the EESC, Luc Van Den Brande from the Committee of the Regions, another EU institution that provides a voice for sub-national European regions within EU policy making, and David Garrahy, representing the European Youth Forum, a civil society platform for European youth organisations. This workshop, as the focus of this critical review, is discussed in more detail below.

Workshop three looked at what support ECl organisers can draw upon during their signature collection campaigns in order to enhance their chances of successfully obtaining the required one million signatures. This panel did not include any academic speakers, but there was a mix of representatives of EU institutions, including Irini Pari from the EESC, Lucy Swan from the Secretariat General of the European Commission and Tina Nilsson from the European Ombudsman's office, as well as civil society representatives Carsten Berg from the ECI Campaign and Sophie von Hatzfeldt from Democracy International. This workshop was primarily a networking opportunity for those civil society representatives present who were considering proposing an $\mathrm{ECl}$ to obtain guidance and information from those with experience and expertise in the process.

The conference closed with a final plenary debate about how to forge change in the $\mathrm{ECl}$ from a civil society perspective. The speakers were primarily from civil society organisations: Carsten Berg from the $\mathrm{ECl}$ Campaign, Assya Kavrakova from ECAS and Mads Hvid from the ECl 'Fair Transport Europe'. They were joined by a representative of the EESC, Antonio Longo, to address the questions of the progress of European democracy since the introduction of the $\mathrm{ECl}$, the extent to which the $\mathrm{ECl}$ has fulfilled expectations and what we can expect in terms of participatory democracy in the EU in the future. In this discussion the $\mathrm{ECl}$ was compared to a cactus in a desert by Kavrakova, who suggested that at present it lacks the necessary infrastructure to determine whether or not it is an oasis and therefore a real opportunity for increased participatory democracy in the EU, or not.

\section{Critical reflection on the workshop 'what future for participatory democracy in the EU?'}

The interaction of academics, policy makers and civil society representatives took place most explicitly within the second workshop where individuals of all three groups were speakers on the panel (including myself), although the participants and audiences of all 
workshops included individuals from a range of backgrounds and perspectives. The second panel was also the highest attended of the three. Critical reflection is focused on this second workshop with the central question 'what future for participatory democracy in the EU?'.

Discussions during the workshop focused on three core questions informed by Kant's Critique of Pure Reason (2007): what can we know, or what can the $\mathrm{ECl}$ teach us about participatory democracy more broadly?; what should we do, or what can we do to strengthen participatory democracy in the EU?, and what may we hope, or what would be a participatory democracy utopia in the EU? Each of the panelists were given five minutes to answer each question, followed by ten minutes of questions and answers from the audience. At the end of the question and answer session, a vote was taken on whether the audience and participants agreed or disagreed with a controversial statement regarding the future of participatory democracy in the EU. These statements were: participatory democracy will always be better than other forms of government; we should require our governments to open digital consultations for every special summit of the European Council, and a utopian model of democracy is a digital democracy, where there are no boundaries to political participation and it becomes a reflex. The audience response to all three of these statements was a majority in support, though notably there was a small number of audience members who disagreed with the statements. When questioned, two of the participants who did not agree reported feeling sceptical about the desirability and effectiveness of participatory democracy in general.

Questions from the audience indicated interest in academic research and how it can inform the development of participatory democracy throughout Europe. For example a question was raised about existing research considering the importance of national political cultures for engagement with and acceptance of instruments of participatory democracy. There was a generally positive response from the audience to the interactions of the panelists, who all agreed that there is potential for improved participatory democracy in the future of the EU. Some civil society and general public audience members noted a welcome focus on the bigger picture and bringing the discussion of the $\mathrm{ECl}$ back to its overall purpose and situation within the democratic system of the EU as a consequence of this, in contrast to the more recent focus on the specific details of the $\mathrm{ECI}$ Regulation.

It is also clear from the video and written outcomes of the conference that one of the key messages from the day was consistent with the overall conclusion of this workshop. It is possible to identify a general conclusion from the ECI Day, that there is a need for a multi-level and 
holistic approach to participatory democracy in the EU, and in order to improve the future for the EU's participatory democracy it is necessary to begin with education. Enhancing education related to European affairs will enhance inclusion in political participation and in turn boost participatory democracy.

This conclusion was informed by the experience and collaboration of the speakers and their different backgrounds. Academia contributed the framework for the discussion, drawing on the questions from Kant's (2007) classical text of philosophy, and added a theoretical dimension to the proceedings, highlighting the basis of participatory democracy in equality and maximum inclusion in politics. This was reflected upon through the experience of civil society organisations. In particular, the input of David Garrahy of the European Youth Forum, drawing on his practical experience, emphasised the significance of engaging young people and socialising them to the EU political system in order to facilitate their political participation throughout their lives.

Representatives of the political institutions contributed to the conclusion from their policy and institutional perspectives by stressing the importance of the EU's multilevel governance in enhancing participatory democracy in the EU as a whole, including Luc Van Den Brande's consideration of the EU's sub-national regions and the role they can play. The collaboration between the participants from these three distinct backgrounds, along with inputs from a broad audience, produced a clear conclusion to the workshop that was informed by theory, practice and policy.

\section{Outcomes, successes and challenges}

In addressing the overall aims of the conference, of enhancing the effectiveness of the $\mathrm{ECl}$, there was a clear difference of opinion on the $\mathrm{ECl}$ between the European Commission on the one hand and representatives of the other EU institutions and civil society organisations on the other. The latter camp appeared to see the capacity to improve the impact of the $\mathrm{ECl}$ within the current rules as limited, although still necessary, and repeatedly lamented the Commission's lack of willingness to revise the Regulation and the absence of the Commissioner throughout the event. This therefore remains a major obstacle to the impact of the collaboration efforts between the numerous stakeholders participating in the event to improve participatory democracy in the EU.

During the conference all participants were asked to contribute anonymously to a collection of the greatest successes and challenges experienced by the $\mathrm{ECl}$ to date. A preliminary consideration of these 
responses categorises them into four successes (its continued existence; the number of citizens who have participated so far; raising public awareness of transnational issues, and increasing debate on participation and democracy at subnational, national and transnational levels) and five disappointments (no legislative proposals generated by the Commission; no revision of the Regulation by the Commission; lack of communication and awareness of the $\mathrm{ECl}$ amongst the people; technical hurdles related to the collection of signatures, and a waning interest in using the $\mathrm{ECl}$ ) (EESC 2016). Some of these reflect directly the discussions held in the second workshop and its conclusion, including the lack of communication and awareness of the $\mathrm{ECl}$ closely tying in with the agreement of the workshop participants that civic education is needed for EU citizens.

The EESC will be preparing a review of the $\mathrm{ECl}$ based on the outcomes of the workshops and these successes and disappointments. When this emerges the extent to which the productive collaboration between academics, policy makers and civil society representatives at the event is able to 'forge change' will become clearer.

\section{Acknowledgements}

The author would like to thank the European Economic and Social Committee for the invitation and funding to attend and speak at the $\mathrm{ECl}$ Day 2016 conference. 


\section{References}

EESC (2016), ECI DAY 2016: Forging Change Report on the ECI's Greatest Successes and Disappointments, Brussels, http://www.eesc.europa.eu/resources/docs/eci-day-2016-report.pdf, accessed 20 April 2017

European Union (2007), 'Treaty of Lisbon Amending the Treaty on European Union and the Treaty Establishing the European Community', Official Journal of the European Union, 50 (C 306): 1-230

European Union (2011), 'Regulation (EU) No 211/2011 of the European Parliament and of the Council of 16 February 2011 on the Citizens' Initiative', Official Journal of the European Union, L 65

Kant, Immanuel (2007), Critique of Pure Reason, Weigelt, Marcus (ed.), London: Penguin Classics

More than education - Shaping active and responsible citizens (2016), 'European Citizens' Initiative on Civic Education in Europe', http://morethaneducation.eu.webhosting126.transurl.nl/europeancitizens-initiative-on-civic-education-in-europe/\#pgc-103-2-0, accessed 30 June 2016

The ECI Campaign (2016), 'ECl'S "existential Crisis" at ECI Day 2016: Commission's Non-Action Frustrates Stakeholders', http://www.citizensinitiative.eu/ecis-existential-crisis-eci-day-2016-commissions-non-actionfrustrates-stakeholders/, accessed 20 May 2016

\section{To cite this article:}

Hatton, L. (2017). 'Forging change'? Collaboration between policy makers, academics, and civil society stakeholders at the ECI Day 2016. Exchanges: The Warwick Research Journal, 4(2), 219-226. Retrieved from: http://exchanges.warwick.ac.uk/index.php/exchanges/article/view/119 